\title{
Bijeg iz socijalističke Jugoslavije - ilegalna emigracija iz Hrvatske od 1945. do početka šezdesetih godina 20 . stoljeća
}

DOI: $10.11567 /$ met.31.2.1 UDK: 314.74:343.343.6](497.13)"1945/1961"

Pregledni rad

Primljeno: 19. 05. 2015.

Prihvaćeno: 14. 10. 2015.

\author{
Tatjana Šarić \\ Hrvatski državni arhiv, Zagreb \\ tsaric@arhiv.hr
}

\section{SAŽETAK}

U poslijeratnoj je socijalističkoj Jugoslaviji politička i/ili ekonomska situacija postala neprihvatljiva za dio populacije. Budući da legalno iseljavanje iz Hrvatske nije bilo dozvoljeno, od završetka Drugoga svjetskog rata rastao je broj ilegalnih emigranata. Rad se bavi upravo tom skupinom emigranata, i to poredbenom analizom izvorne arhivske građe i dostupne literature od 1945. do 1961., kada država postupno otvara granice. Ilegalno su emigrirali većinom mladi ljudi, do 25 godina, i to prije svega iz ekonomskih razloga, što je povezano s tradicijom emigracije, pogotovo u priobalnom području. Osim zbog loše ekonomske situacije emigriralo se i iz političkih razloga, zatim iz avanturizma, zbog izbjegavanja služenja u JNA ili bijega pred zakonom zbog počinjenih kaznenih djela. Bježalo se kopnenim ili, što je bilo mnogo uspješnije, morskim putem. Najčešće prvo odredište emigranata bile su Italija, Austrija i Njemačka, odakle se većina prebacivala u prekomorske zemlje. Najviše je ljudi bježalo iz tadašnjih kotareva Rijeka, Pula, Zagreb, Zadar, Šibenik i Split, iz kojih je potjecalo $74 \%$ svih ilegalnih emigranata. Prebjezi su većinom bili radnici, zatim zemljoradnici, učenici škola u privredi, službenici, učenici i studenti, pomorci i obrtnici. Prema rodnoj pripadnosti, među prebjezima je bilo mnogo više muškaraca nego žena, od kojih je većina bila neoženjena. Vlasti su radile na sprečavanju bijega u inozemstvo metodama nadzora granice i zatvorskim kaznama, ali i pokušajima osiguravanja boljih životnih uvjeta na ugroženim područjima. Budući da te mjere nisu dale željene rezultate, ali i zbog početka gospodarske krize te pojave nezaposlenosti, vlasti su liberalizirale postupke iseljavanja i otvorile granice iseljenicima, što je dovelo do novog vala ekonomske emigracije.

KLJUČNE RIJEČI: socijalizam, FNRJ, Hrvatska, emigracija, ilegalno iseljavanje, mladi 


\section{UVOD}

Povijest iseljavanja stanovništva iz Hrvatske duga je, a razlozi su u pojedinim razdobljima bili raznoliki. Počevši od bijega pred osmanskim osvajanjima u 15. stoljeću do najvećeg vala iseljavanja zbog posvemašnje neimaštine koji je krenuo krajem 19. stoljeća, tekao kroz prvu polovinu 20., nakratko bio prekinut Prvim svjetskim ratom te se nastavio do Drugoga svjetskog rata, iseljavanje je bilo kontinuirano. Tijekom vremena je iseljavanje iz $\mathrm{Hr}-$ vatske, pogotovo s područja Dalmacije i otokâ u prekomorske zemlje, postalo tradicijom (Lajić, 1992).

U ovom se radu neće ulaziti u raščlambu povijesnog tijeka iseljavanja ni $\mathrm{u}$ analizu iseljavanja pojedinih skupina stanovništva, tadašnje ekonomske, lančane migracije do 1945. Znanstveni interes usmjeren je na razdoblje neposredno nakon Drugoga svjetskog rata. Tada je emigracija stanovništva iz Hrvatske zbog, prije svega, turbulentnih političkih događaja bila u velikoj mjeri raznorodna - izbjeglice, osobe koje su prisilno odvedene u inozemstvo kao ratni zarobljenici ili prisilni radnici te su tamo i ostale (samo ih je dio repatriran), pripadnici Oružanih snaga Nezavisne Države Hrvatske (NDH) koje su se povukle pred jedinicama Narodnooslobodilačke vojske i Partizanskih odreda Jugoslavije (NOV-a i POJ), optanti, tj. stanovnici talijanske narodnosti pripojenih krajeva koji su se opredijelili za iseljavanje u Italiju, protjerani ili iseljeni Nijemci, Česi, Mađari, Poljaci i pripadnici drugih nacionalnih skupina te prebjezi u prvim poratnim godinama (Dukovski, 2001a, 2001b; Geiger, 2002; Karakaš-Obradov, 2013, 2014; Nejašmić, 2014; Radelić, 2006; Selinić, 2010; Žerjavić, 1993: 635-636). Predmet ovoga rada jest ilegalna emigracija iz Hrvatske $u$ prvih petnaestak godina nakon Drugoga svjetskog rata, koja je većinom obuhvaćala mlade ljude do 25 godina.

Što je uzrokovalo tu vrstu emigracije? Tijekom Drugoga svjetskog rata utemeljena je Jugoslavija pod vlašću Komunističke partije Jugoslavije, koji su završetkom rata nastojali učvrstiti svoju vlast. Nova se vlast međutim prvih poslijeratnih godina suočavala s brojnim izazovima - posvemašnjim siromaštvom u ratom razorenoj zemlji i potrebom njezine obnove, ubrzanom industrijalizacijom zemlje, potrebom opismenjavanja, obrazovanja i osposobljavanja posebice mladog stanovništva za podizanje industrije i poljoprivrede kao i težnjom za, u tadašnjem sustavu obveznom, ideološkom »nadgradnjom « radi stvaranja socijalističkog ideala pojedinca (Šarić, 2011: 142-146, 194-198). Krajem rata komunistička se vlast, što fizičkim uništenjem, što političkim odlukama, obračunala i sa stvarnim i s potencijalnim 
političkim protivnicima svog režima, što se, u nešto manjoj mjeri, nastavilo i sljedećih godina konsolidacije njihove vlasti (Goldstein, 2008: 369-381).

Raskid s državama članicama Informbiroa na čelu sa SSSR-om 1948. dodatno je pogoršao jugoslavensku gospodarsku te vanjskopolitičku situaciju, pri čemu je Jugoslavija bila prisiljena tražiti treći put, izvan okvira sovjetske verzije socijalizma s jedne te kapitalizma zapadnih demokracija s druge strane. Od 1950. postupno je krenula od tzv. »etatističkog centralizma« putem novoosmišljenoga »samoupravnog socijalizma«, čime je vodstvo države načelno označilo raskid s dotadašnjim centralističkim i planskim načinom upravljanja gospodarstvom te odmak od dotadašnjeg uzora SSSRa. Na Šestom kongresu KPJ 1952. učinjen je završni korak u udaljavanju od ideološke podloge sovjetskog socijalizma te je tada i promijenjen naziv KPJ u Savez komunista Jugoslavije (SKJ), označujući tako formalnu transformaciju Partije u liberalniju formu Saveza. U to vrijeme počinje formalno odvajanje Komunističke partije od aparata vlasti, iako je zadržala svu vlast u rukama. Šesti kongres KPJ potvrdio je novi smjer samoupravnog socijalizma i deetatizacije, a na njemu je radikalizirana kritika staljinizma i sovjetskog režima te verificiran novi smjer jugoslavenske politike (Goldstein, 2008: 473; Radelić, 2006: 287-288). Jugoslavija se od tada više otvara Zapadu, putovnice se izdaju u većem broju, a slobodnija su i putovanja u inozemstvo određenim skupinama stanovništva (sportaši, pisci, studenti) (Radelić, 2006: 291). Od Staljinove smrti 1953. postupno se normalizira i odnos sa SSSR-om i državama Istočnog bloka (Goldstein, 2008: 483-485).

Početkom pedesetih godina 20. stoljeća u Jugoslaviji tako dolazi do određenog ublažavanja dotadašnje stege upravnog i partijskog aparata i dopuštanja više sloboda stanovništvu, no unatoč tomu dio je stanovništva ostao nezadovoljan političkom i gospodarskom klimom u zemlji. Veliki se dio stanovništva, doduše, priklonio uvjetima življenja u takvu obliku države i društvenog uređenja, no bilo je i onih koji nisu mogli ili željeli pristati na život u takvim uvjetima.

Jedan od izraza nezadovoljstva stanovnika životom u Jugoslaviji bio je i bijeg $u$ inozemstvo. Među prebjezima prednjačili su mladi koji su se bijegom $\mathrm{u}$, prije svega, zapadne i prekomorske zemlje nadali ostvarenju ideala o lagodnijem i slobodnijem životu. Ovdje će biti riječi upravo o njima.

Valja spomenuti kako je u ovom razdoblju, osim tendencije dijela stanovništva za iseljavanjem iz države, paralelno postojalo i jako nastojanje vlasti za povratkom ekonomske prijeratne emigracije u Jugoslaviju iz prekomorskih zemalja. Od 1945. do 1951. vratilo se oko 16.000 iseljenika, od 
kojih se dio zbog loših životnih uvjeta ponovno vratio u zemlje iz kojih je došao (Karakaš-Obradov, 2014: 110-112; Lalić, 2010: 66-124).

Budući da je literatura o specifičnoj temi ilegalnih iseljenika vrlo oskudna, nastojat ćemo rasvijetliti fenomen bijega većinom mladih ljudi u inozemstvo analizirajući podatke iz, najvećim dijelom, dostupnih arhivskih izvora te pokušati pružiti informacije o broju bjegunaca, njihovu socijalnom statusu, zanimanju i dobi, područjima iz kojih su bježali te o razlozima bijega, očekivanjima bjegunaca i postupcima s uhvaćenima. Vremenski je okvir razdoblje od završetka Drugoga svjetskog rata do 1961. Ta je godina odabrana zbog dva razloga. Prvi je postupno povećavanje razina osobnih sloboda stanovništva u smislu slobode kretanja, koja tada počinje te se i režim izdavanja putovnica, pogotovo od 1962., liberalizira - osim odabranim skupinama one se u većem broju izdaju i široj populaciji. Drugi je razlog postojanje informacija o ovoj temi u arhivskoj građi, koje sežu do 1961. te se time podudaraju s postupnom liberalizacijom slobode kretanja stanovništva, čime je problematika bijega počela gubiti na aktualnosti.

Osim povećanog broja turističkih putovanja razlog otvaranja granica ležao je i u odluci vlasti da se zbog povećane nezaposlenosti uzrokovane gospodarskim reformama i sve veće nezaposlenosti građanima dopusti slobodno zapošljavanje u inozemstvu (Radelić, 2006: 315, 316; Bilandžić, 1999: 390).

O ilegalnoj emigraciji mladih iz Jugoslavije od 1945. do 1961. postoji relativno malo podataka i u izvorima i u literaturi, pogotovo za razdoblje do 1950. Podaci koje imamo za te prve godine socijalizma oskudni su, sporadični i nepotpuni. Od 1953. nešto su potpuniji, ali ne postoje ni za sve godine ni za cijelo područje NRH. Među izvorima valja spomenuti naročito vrijedan detaljan izvještaj iz 1956. »Problem bijega u inozemstvo (HDA-RK SSOH-KIPR, 1956; HDA-IVS-OUP, 1956) koji je izradila posebna komisija formirana unutar CK SKH sa zaduženjem istraživanja i analize problema bijega u inozemstvo. Taj je izvještaj u tekstu citiran iz nekoliko arhivskih fondova jer su važnije materijale partijska tijela slala na uvid ili analizu tijelima javne uprave i obratno.

Podatke o bijegu preko granice evidentirali su odjeli za unutrašnje poslove narodnih kotareva, koji su podatke slali Ministarstvu/Državnom sekretarijatu za unutrašnje poslove NRH, čija je arhivska građa, nažalost, nedostupna istraživačima, ali se dio podataka može rekonstruirati iz drugih, dostupnih arhivskih fondova. Evidenciju o bijegu mladih vodili su od polovine pedesetih i Organizacijsko-politički sekretarijat Centralnoga komiteta Saveza komunista Hrvatske (CK SKH) te kotarski komiteti Narodne omla- 
dine Hrvatske (NOH), koji su o tome izvještavali više strukture omladinske organizacije. $\mathrm{NOH}$ je djelovao kao omladinska politička organizacija pod patronatom i u okviru programa Komunističke partije (KP) odnosno Saveza komunista (SK) te je predstavljao njezinu rezervu iz koje su se regrutirali potrebni kadrovi za sve grane državne uprave i gospodarstva, kao i za masovne organizacije (Šarić, 2011).

Pitanjem bijega mladih bavila se u okviru NOH-a Komisija za ideološkopolitički rad, a i partijska i omladinska tijela vodila su o tom problemu svoje evidencije te su se razmatrali načini njegova rješavanja i uzroci tog oblika emigracije.

\section{RAZLOZI ZA BIJEG}

Bijeg mladih $\mathrm{u}$ inozemstvo bio je u Federalnoj Hrvatskoj (FH) i Narodnoj Republici Hrvatskoj (NRH) aktualan još od završetka Drugoga svjetskog rata. Zbog čega su mladi bježali iz zemlje? Razlozi su bili višestruki, a u većini je slučajeva odluka o bijegu bila rezultat zbroja nekoliko razloga. Ipak, dva su bila osnovna: politički i ekonomski. Iako je stav dijela vladajućih struktura bio da je svaki ilegalni bijeg preko granice ustvari politički čin i da ga kao takav treba promatrati (HDA-RK SSOH-KIPR, 1956), ovdje će se analizirati svaki razlog zasebno.

Politički razlozi načelno su značili neslaganje s postojećim državnim i društvenim sustavom - jezikom izvorâ, to su bile »neprijateljske pobude«. U tu kategoriju možemo ubrojiti sve vrste političkih protivnika komunističke vlasti i socijalističkoga društvenog poretka, a od 1948. i sukoba jugoslavenskog vrha s Informbiroom, te otpadnike od Komunističke partije, stvarne i navodne pristaše SSSR-a i Staljinove politike. Zbog sukoba sa SSSR-om u ljudi se razvio i strah od moguće ratne opasnosti, što je također u određenoj mjeri utjecalo na odluku o bijegu iz zemlje.

Budući da je područje Hrvatske tijekom Drugoga svjetskog rata u velikoj mjeri bilo politički polarizirano, vjerojatno je da poraženi završetkom rata i promjenom političkih pozicija moći nisu tek tako zaboravili svoja dojučerašnja politička stajališta. Iako je veliki dio političkih protivnika komunističke vlasti uništen u poslijeratnim progonima, dok su drugi nakon povlačenja pred partizanima ostali u inozemstvu, dio protivnika režima ostao je u zemlji. Među njima, osim ostalih grupacija, treba tražiti i nezadovoljnike koji su ilegalno emigrirali.

Kod mladih ljudi okidač za bijeg bio je i osjećaj određene "zapostavljenosti« od sustava, što se primjerice naročito očitovalo kod talijanske manjine 
u NRH (HDA-RK SSOH-KIPR, 1961a, b; HDA-IVS-OUP, 1956). Talijanima je međutim omogućen izlaz iz takve situacije - od 1948. mogli su, za razliku od Hrvata, legalno emigrirati, što je uređeno Odredbama o opcijama Ugovora o miru s Italijom iz 1948. i 1951., a trajalo je do kraja 1953. No iseljavanje Talijana iz hrvatskih krajeva, poticano i od vlasti, počelo je i prije tog dogovora, od kraja Drugoga svjetskog rata, kao posljedica ratne podjele te neriješenog pitanja granica. Prema procjenama više istraživača, iz Hrvatske se tada iselilo između 100.000 i 350.000 Talijana, a prema Centru za povijesna istraživanja u Rovinju, 201.440 (Dukovski, 2001a: 219, 229; Karakaš-Obradov, 2014: 318-334; Nejašmić, 1991, 2014: 414; Radelić, 2006: 53; Žerjavić, 1993).

Krajevi iz kojih je otišlo najviše stanovnika bili su Istra te zadarsko područje, u kojima je talijanska manjina bila i najzastupljenija. Osim putem opcija Talijani su emigrirali i otpuštanjem iz državljanstva te ilegalno. Hrvati nisu imali mogućnost optiranja, ali su tome nastojali doskočiti predstavljajući se Talijanima (jer je odrednica nacionalnosti pri dobivanju dozvole za optiranje bila materinji/govorni jezik, talijanski ili hrvatski, što se u dvojezičnoj sredini moglo i lažirati) te se dio Hrvata i na taj način iselio iz zemlje (Dukovski, 2001b: 227-228). Oni koji u tome nisu uspjeli ostali su u zemlji ili su emigrirali ilegalno.

Iako se u literaturi pojavljuju tvrdnje kako su od 1946. do 1955. iz zemlje ilegalno emigrirali samo »ideološki neprijatelji«, a nakon toga $\mathrm{i} »$ kriminalci, avanturisti i sl.« (Karakaš-Obradov, 2014: 112), to nije potpuno točno. Činjenica je da su vlasti od kraja četrdesetih počele voditi evidenciju o bjegovima te potom i izrađivati detaljne analize o pojavi ilegalne emigracije $u$ svim njenim aspektima, pa tako i o razlozima bijega, iz kojih se vidi kako u navedenom razdoblju nisu emigrirali samo »ideološki neprijatelji«. Kao potvrda tog zaključka može nam poslužiti analiza razloga za bijeg Izvršnoga komiteta CK SKH iz 1954. U njoj se navodi kako je 63\% bjegunaca u 1954. bježalo zbog "ekonomskih razloga, avanturizma i drugih pobuda«, $19 \%$ zbog »neprijateljskih pobuda «, $12 \%$ zbog »izbjegavanja vojne obveze«, a 5\% zbog »izbjegavanja krivične odgovornosti i izvršenja kazni« (Vojnović, 2008: 178). Očito je dakle da je većina prebjega iz Jugoslavije, osim zbog svjetonazorskih i ideoloških neslaganja s režimom, zapravo bježala zbog vjerojatnijih i važnijih razloga - ekonomskih.

Što je dovelo do toga? U prvim poslijeratnim godinama $\mathrm{u}$ mnogim je krajevima, a pogotovo u priobalju te Lici, Kordunu i Baniji, gospodarska situacija bila teška. Opskrba i prehrana stanovništva bile su oskudne, a lošoj ekonomskoj situaciji pridonijele su i vladine mjere konfiskacije i nacio- 
nalizacije privatnog vlasništva te kolektivizacije agrara radi »socijalističkog preobražaja sela« (Radelić, 2006: 178-198, 205-208; Bilandžić, 1999: 223; Maticka, 1990: 48).

Mnogi nisu mogli pronaći posao te stoga ni način na koji bi prehranjivali sebe i svoju obitelj. Na otocima je jedan od razloga takve situacije bila i tradicionalna orijentacija stanovništva na more i plovidbu, gdje međutim nije bilo dovoljno posla za sve, a za druge vrste poslova otočani nisu bili zainteresirani, zaključeno je o toj temi na jednoj sjednici Izvršnoga komiteta CK SKH (Vojnović, 2008: 179). Nedostatak inicijative u traženju zaposlenja u drugim dijelovima države vlast je nerijetko poistovjećivala s nedostatkom domoljublja. Postavljalo se pitanje kako to da ako primjerice u Vojvodini nedostaje ljudstva za berbu kukuruza i šećerne repe, nitko iz priobalja, iako u svom kraju nema posla, ne želi otići raditi u druge krajeve države (HDACK SKH-OPS, 1959).

Najviše je nezaposlenih pomoraca bilo u kotarevima Zadar i Šibenik. No problem pri njihovu zapošljavanju bio je i administrativne prirode. Naime moreplovnice - dozvole za plovidbu, izdavane su osobama do 25 godina. Ako se ta osoba ne bi uspjela ukrcati na brod u roku od četiri godine, moreplovnica je zastarijevala i nije se mogla produžiti. Od 1945. do 1957. izdano je tako 5010 moreplovnica, a deset godina poslije 2736 njih nije bilo upotrijebljeno. Dakle više od polovine pomoraca nije u tom razdoblju uspjelo dobiti posao. U takvim slučajevima mladi su se često odlučivali na bijeg. Oni koji su se uspjeli ukrcati nerijetko su pak bježali s brodova u inozemnim lukama zbog mnogo većih plaća na stranim brodovima (HDA-RK SSOH-KIPR, 1956).

Osim nedovoljnog broja radnih mjesta za pomorce, i pri odabiru osoba za ukrcaj postojale su nepravilnosti; zapošljavanju su nerijetko kumovale privatne veze moćnijih pojedinaca. Primjer za to jest situacija u Preku na otoku Ugljanu. Mladić slaboga ekonomskog statusa čekao je na ukrcaj četiri godine, dok se istovremeno našlo mjesto za jednoga, a zatim i drugoga sina najbogatije obitelji u mjestu. Otac tih mladića bio je, prikladno, blizak s tajnikom općine. Sin lokalnoga moćnika koji je prvi ukrcan ostao je u Americi pri prvom pristajanju broda (HDA-CK SKH-OPS, 1959).

Iako su se mnogi pomorci željeli ukrcati na strane brodove, to je u FNRJ do travnja 1956. bilo zabranjeno. Slijedom promjene političkih prilika i otvaranja Jugoslavije prema Zapadu te kako bi se riješio problem nezaposlenosti pomoraca i njihova ekonomskog statusa, tada je ukrcavanje na strane brodove Odlukom Odbora za unutrašnju politiku Izvršnog vijeća FNRJ dozvoljeno (HDA-CK SKH-OPS, 1957). 
Osim pomoraca i mnogi su se drugi, zbog siromaštva te mogućnosti višestruko veće zarade $u$ inozemstvu, odlučivali na bijeg $u$ zapadne zemlje, odakle bi obiteljima slali novac. Nada u bolji život i standard tjerala je mlade iz Jugoslavije, čemu su pogodovali i prijeratni ekonomski iseljenici koji su u zapadnim zemljama uspjeli svojim obiteljima omogućiti život pristojna standarda te su svojim rođacima u Jugoslaviji slali pakete i nadu u mogućnost lakšeg života. Rodbinske i prijateljske veze u inozemstvu igrale su veliku ulogu pri odlukama za bijeg (HDA-RK SSOH-KIPR, 1956). Tradicija ekonomske emigracije, koja je bila uvelike prisutna, pogotovo u obalnom pojasu NRH, podrazumijevala je običaj da ako unutar jedne obitelji postoji više sinova, jedan od njih emigrira. Roditelji s više muške djece još bi u djetinjstvu određivali koji će sin biti nasljednik imanja, koji će u emigraciju, a koji u navigaciju te su ih tako i odgajali. Kad bi postala punoljetna, djeca određena za emigraciju, ako nisu mogla otići legalnim putem, činila bi to ilegalno (HDA-CK SKH-OPS, 1957). Korčula je primjerice jedan od otoka s jakom tradicijom emigracije.

Zahvaljujući takvoj praksi oko 60\% ilegalnih prebjega već je imalo rodbinu $u$ inozemstvu, većinom u prekomorskim zemljama, gdje su formirane i zajednice hrvatskih iseljenika, često prema mjestima podrijetla (Mesarić Žabčić, 2014: 77-87). Stoga je mnogo bjegova posljedica nastojanja spajanja s članovima obitelji koji su već bili u inozemstvu - primjerice kada bi žena s djecom odlazila za mužem koji je ilegalno izbjegao, što jugoslavenske vlasti većinom nisu odobravale legalnim putem. Zašto bjegunci nisu od vlasti tražili dozvolu za odlazak u inozemstvo? Zato što je praksa u Jugoslaviji bila odobravanje vrlo malo molbi za iseljenje - NR Hrvatska tako je 1955. odobrila iseljenje za samo 1048 osoba, a u 1956. za 1492, dok ih je istovremeno odbijeno 526. U 1957. odobreno je 1958 iseljenja, a odbijeno 294 (HDA-CK SKH-OPS, b.g). Iseljenje se $u$ to vrijeme odobravalo samo onima koji su već imali rodbinu u inozemstvu, ponekad i radi »spajanja obitelji« te osobama koje su išle preuzeti nasljedstvo ili posao. Događalo se i da potencijalni iseljenici koji su i uspjeli dobiti jugoslavenske putovnice nisu dobili ulazne vize zemalja u koje su željeli emigrirati, pa su nastojali do njih doći ilegalnim putem (HDA-CK SKH-OPS, 1957). Rođaci iz inozemstva, ali i ilegalni prebjezi koji su se uspjeli materijalno osigurati u inozemstvu u Jugoslaviju su nerijetko slali vrijedne poklone poput kinoaparature, kućanskih aparata ili glazbenih instrumenata, čime su dodatno budili želju za odlaskom među onima koji su ostali. U 1955. je tako svaki četvrti stanovnik otoka zadarskog arhipelaga primio poklon-paket od rodbine $u$ emigraciji, a vrijednost paketa poslanih samo preko pošte, što ne uključuje špediterska poduzeća, koja 
su prevozila vrednije i veće pakete (radioaparate, hladnjake, skuplje tkanine itd.), u toj godini na zadarskom području iznosila je 46 milijuna dinara, na šibenskom 53, a na karlovačkom 25 milijuna dinara (HDA-CK SKH-OPS, 1957). Osim u vrijednim pošiljkama stanovništvo je pomoć »izvana« dobivalo i u gotovini, a mnogi su primali i mirovine kao emigranti-povratnici, koje su bile mnogo veće od »domaćih«. Zanimljivo je kako se na otoku Olibu primjerice kupoprodaja nekretnina formalno obavljala u dinarima, ali isplata se provodila isključivo u dolarima, tj., prema rječniku otočana, u »zdravoj valuti« (HDA-IVS-OUP, 1956). Zbog materijalne osiguranosti rodbine $\mathrm{u}$ inozemstvu i mnoge su se kompletne obitelji odlučivale na bijeg. U 1956. je primjerice pobjeglo 228 obitelji s 595 članova (HDA-RK SSOHKIPR, 1956).

$\mathrm{Na}$ ilegalno iseljavanje stanovništva osim tradicije emigracije utjecali su i drugi čimbenici: elementarne nepogode, slab ulov ribe, a kod zemljoradnika i nemogućnost uzdržavanja mnogo članova domaćinstva na malim parcelama zemlje.

Ako pogledamo zanimanja ilegalnih emigranata (tablica 1), među njima je polovinom pedesetih bilo najviše radnika, zatim zemljoradnika te učenika škola u privredi, službenika, učenika i studenata, pomoraca, obrtnika i drugih zanimanja.

Tablica 1. Zanimanje ilegalnih emigranata 1956.

Table 1. Vocation of illegal emigrants, 1956

\begin{tabular}{lc}
\hline Zanimanje & Udio \\
\hline radnici & $59,7 \%$ \\
\hline zemljoradnici & $15,5 \%$ \\
\hline učenici škola u privredi & $4,7 \%$ \\
\hline službenici & $4,5 \%$ \\
\hline učenici i studenti & $2,7 \%$ \\
\hline pomorci & $2 \%$ \\
\hline obrtnici & $0,9 \%$ \\
\hline ostala zanimanja & $10 \%$ \\
\hline
\end{tabular}

Izvor: HDA-RK SSOH-KIPR, 1956.

Zašto su većinom bježali baš radnici? Iz vrlo jednostavnog razloga - zato što od svoje plaće nisu mogli živjeti i tražili su bolje životne uvjete. To se prije svega odnosi na mlade radnike početnike te one nekvalificirane, čije su plaće bile znatno manje od onih starijih, iskusnijih i kvalificiranih radnika. Tako je 1957. plaća mladog radnika u Puli bila između 8000 i 9000 dinara, 
dok su samo troškovi prehrane u menzi iznosili 8000. Sve ostale troškove taj radnik dakle nije mogao podmiriti (HDA-CK SKH-OPS, 1957). Povrh toga, nerijetko ni isplata tih malih plaća nije bila redovita - $\mathrm{u}$ prvih devet mjeseci 1956. više od sedamsto poduzeća u NRH svojim radnicima nije redovno isplaćivalo plaće ili ih uopće nije isplatilo (Radić, 1999: 151). Osim male zarade mladi radnici samci nisu mogli riješiti ni stambeno pitanje jer su stanovi dodjeljivani samo oženjenima. Samci su tako bili prepušteni samovolji stanodavaca koji su određivali stanarine. Nekoliko godina poslije, 1960., prosječna plaća radnika povećala se i bila je 16.705 dinara, dok je ona službenika u privredi, za usporedbu, bila znatno veća - 22.138 dinara (HDA-RK SSOH-KIPR, 1961a).

Bilo je slučajeva da su mladi osim zbog teških ekonomskih prilika bježali i zbog nedjelotvornosti sustava. U izvorima nailazimo na slučajeve učenika škola u privredi koji su također bili dijelom »radničke klase« zbog tipa školovanja - uz redovnu školu obvezno su prolazili i naukovanje, tj. stručnu praksu u poduzećima ili kod privatnika. Ta je grupacija mladih zbog teških uvjeta života i rada ionako bila jedna od najugroženijih, a njihovu lošem položaju pridonosile su i situacije kada bi bezrazložno bivali izbačeni iz učeničkih domova u kojima su bili smješteni te bi ostajali na ulici, pri čemu im ni nadležne organizacije (primjerice $\mathrm{NOH}$ ) nisu pomagale u rješavanju problema. Bilo je i mnogo primjera ljudi koji su ostali bez posla, a imali su obitelj koju su trebali uzdržavati (HDA-CK SKH-OPS, 1957). U takvim slučajevima ilegalna emigracija bila je jedna od opcija.

Postojale su i situacije kada uzroci emigriranja na istom području nisu bili potpuno jasni vlastima. Zanimljiv je slučaj dvaju susjednih sela: iz jednoga su mladi emigrirali, dok iz drugoga nisu. Pritom su socioekonomski ili politički preduvjeti te rodbinska povezanost s inozemstvom bili jednaki u oba mjesta. Takav je slučaj bio primjerice na Korčuli, s koje su mladi emigrirali iz Lumbarde i Korčule, dok iz Račišća nisu (HDA-RK SSOH-KIPR, 1956).

U mjestima u kojima su bjegovi bili učestali i očekivani lokalna je zajednica obično podržavala bjegunce i pomagala im u pripremama za bijeg, shvaćajući da su uzrok bijegu loše ekonomske prilike. Mnogo je takvih slučajeva bilo i u mjestima čije je stanovništvo formalno i svjetonazorski bilo blisko vladajućem režimu te je i tijekom rata bilo usko vezano uz partizanski pokret. Usprkos tomu iz njih su nerijetko bježali i članovi SK ili djeca poginulih partizanskih boraca, kao primjerice u Bilicama blizu Šibenika (HDA-CK SKH-OPS, 1957). 
Isto tako, u zajednicama u kojima je bijeg postao tradicija bilo je lakše, čak i došljacima, odlučiti se za odlazak iz zemlje na taj način. Primjer za to ponovno je Korčula, kamo se doselio čovjek koji je do tada radio kao vozač u MUP-u FNRJ, bio je član SK i prema svim tadašnjim kriterijima uzoran djelatnik i građanin. No nakon mjesec dana na Korčuli pobjegao je sa ženom i djecom (HDA-CK SKH-OPS, 1957).

Nerijetko se događalo i da se ljudi na bijeg odluče potpuno spontano. U izvorima se taj fenomen objašnjava »atmosferom bijega«. To se dogodilo na seoskom plesu u selu Karbune kod Pazina kada je grupica pijanih mladića nenadano pobjegla ili kad je pastir slučajno naišao na bjegunce koji su se upravo ukrcavali u barku pa im se priključio (HDA-RK SSOH-KIPR, 1956).

Osim političkih i ekonomskih treći veliki razlog za bijeg mladih u inozemstvo bile su takozvane »avanturističke pobude«. »Bježanje omladinaca preko granice smatra se avanturom«, rečeno je na jednoj sjednici Politbiroa CK KPH iz 1950. (Vojnović, 2006: 564). Naime u hrvatske mladeži bijeg na Zapad djelomice je bio posljedicom očaranosti zapadnjačkom kulturom i načinom života koje su mladi upijali kroz filmove, glazbu i literaturu te vizije lakšeg i slobodnijeg života na Zapadu koji su priželjkivali. Bijegu mladih pridonijele su i radioemisije stranih radiostanica koje su slušali te bilteni ambasada zapadnih zemalja koji su raspačavani u Hrvatskoj, a u kojima su se prikazivali uspjesi tih država na raznim poljima, no ponajviše pisma rođakâ i prijateljâ koji su emigrirali te svjedočili o boljim životnim uvjetima (Radelić, 2006: 291; Jakovina, 2003: 406; Vojnović, 2008: 175).

Iako su se mladi koji bi bili uhvaćeni prilikom bijega u velikoj mjeri izjašnjavali da su bježali iz avanturističkih pobuda, i to treba uzeti sa zadrškom. Naime ako bi se prilikom ispitivanja izjasnili da su pobjegli zbog političkih razloga i na taj način bili evidentirani kao politički protivnici režima, posljedice za njih i njihov daljnji život u Hrvatskoj vjerojatno bi bile kudikamo teže nego za mlade »avanturističkog duha«.

Još jedan razlog bježanja mladićâ iz Hrvatske bilo je izbjegavanje služenja vojne obveze u JNA. Ta je pojava bila osobito učestala u Dalmaciji i Istri, a pogotovo u Puli. Zabilježeno je da su mladići već pri regrutaciji izjavljivali: »Možete me regrutovati, ali ja ću prije pobjeći, a neću služiti JNA« (HDACK SKH-OPS, 1959). Jedan od razloga za bijeg bio je i izbjegavanje kaznene odgovornosti za počinjena djela, a kod djevojaka, pogotovo s otokâ, u dosta slučajeva razlog bijega bila je želja za udajom jer u svojim krajevima nisu imale velik izbor potencijalnih ženika. Ponekad su pojedinci bježali i zbog neslaganja u braku, pri čemu im je bilo jednostavnije emigrirati nego tražiti razvod (HDA-RK SSOH-KIPR, 1956). 
Ne treba zanemariti ni činjenicu da je mladima od 18 do 25 godina koji su u većini slučajeva bježali bilo puno lakše donijeti takvu odluku nego starijima, vezanima drugim obvezama uz domovinu. Mladi, najčešće bez vlastite obitelji, nisu imali spone koje bi ih zadržale u »starom kraju«, dok su od inozemstva imali velika očekivanja.

\section{NAČIN BIJEGA}

Na koji su način mladi bježali u inozemstvo? Neki su bježali u vlastitom aranžmanu, ali to je bio manji broj, 30,2\% bjegunaca, dok ih je većina, 69,8\%, bježala organizirano, uz pomoć takozvanih »ilegalaca «. »llegalci« su bili već iskusni prebjezi koji su se nakon uspješnog bijega iz zemlje ilegalno i vratili $\mathrm{u}$ zemlju te se angažirali u pomaganju zainteresiranima pri bijegu na Zapad. Za taj su angažman uzimali prilično velike naknade - 1960. taj je iznos bio 50.000 - 200.000 dinara ili od sto do petsto dolara (HDA-RK SSOH-KIPR, 1961a, b; HDA-IVS-OUP, 1956).

Osim prebjega organizacijom bijega i vođenjem grupa preko granice bavile su se i osobe koje same nisu namjeravale pobjeći, već su se time uzdržavale. U Zagrebu je primjerice bilo poznato nekoliko osoba vodiča koje su na taj način zarađivale. Iako su i ilegalci i vodiči često bivali uhićeni te bi odslužili i zatvorske kazne, redovito su se vraćali svom »poslu«. Godine 1956. uhićeno je primjerice 25 vodiča i »ilegalaca «, i to osamnaest iz Italije i sedam iz Austrije, a najviše ih je uhićeno u kotarevima Pula, Rijeka, Zagreb i Karlovac. Godine 1960. broj se uhićenih povećao - na 49 ilegalaca i 119 vodiča, a do 1. lipnja 1961. uhićeno je još dvadeset ilegalca i 31 vodič (HDARK SSOH-KIPR, 1956).

Bježanje posredovanjem skupih »ilegalaca« i vodiča nosilo je za mahom siromašno stanovništvo i dodatan rizik. Naime kako bi mogli platiti organizatorima bijega, potencijalni prebjezi često su prodavali svu svoju imovinu. Ako bi bili uhvaćeni i vraćeni u zemlju, našli bi se u nezavidnoj poziciji, bez ikakve imovine i sredstava za život.

Kojim se putovima bježalo? Godine 1956. pješice je kopnenim putem bježalo $66 \%$ bjegunaca, morem ih je bježalo manje, njih 29,7\%, a ostali su bježali željeznicom. Ukupno gledajući, postotak uspješnosti bijega išao je u korist bjegunaca morskim putem, kojih je 1956. uhvaćeno tek $27,8 \%$, dok je kopnenih bjegunaca uhvaćeno 54,4\% (HDA-RK SSOH-KIPR, 1956).

Morskim putem bilo je najlakše bježati zato što morsku granicu nije bilo moguće osiguravati toliko kao kopnenu. Iz primorskih kotareva većina je bjegunaca zato birala upravo taj put. Iz grada i kotara Zadar od svih prebje- 
ga $90 \%$ pobjeglo ih je morskim putem, vlastitim brodovima, onima u vlasništvu rođaka ili ukradenim brodovima. S otokâ se najviše bježalo u Italiju, što je bilo učestalo, tajno i dobro organizirano. Uobičajeni način bijega bio je da se grupa bjegunaca prividno uputi u ribolov i jednostavno brodom prijeđe granicu. Drugi je način podrazumijevao kretanje $u$ kasnim poslijepodnevnim ili večernjim satima, tako da se bjegunci tijekom noći udalje od hrvatske obale i među otocima sakriju od patrolnih čamaca nadležnih državnih tijela. Mnoge su bjegunce na udaljenosti od dvadeset do trideset milja od hrvatske obale prihvaćale talijanske ribarice, koje bi ih teglile do najbliže talijanske luke (Vojnović, 2008: 171). O bijegu na Zapad mladi su čak i javno pjevali prikladne pjesme - jedna je djevojka u selu Privlaci kod Zadra uz kolo pjevala: »Sretno dragi stigo u Anconu, osam dana, mi ćemo za vama!« te zatim: »Sve ja brojim dane i minute, Italijo kad ću doći u te!« (HDA-CK SKH-OPS, 1959).

Kako bi spriječile bjegove, vlasti su donijele odredbe o ograničavanju kretanja na otvorenome moru za brodice i zabrani noćnog ribolova, a vlasnici brodica morali su u slučaju otuđenja ili nestanka broda plaćati visoke novčane kazne (Spehnjak, 2006: 295). Osim toga vlasnici brodova - zadruge, ribarska poduzeća ili privatne osobe, nastojali su osigurati brodove od krađe tako da bi dio posade ostajao na njima tijekom noći ili bi skinuli dijelove motora, čime bi i privremeno onesposobljavali brodove za plovidbu (HDACK SKH-OPS, 1959).

Najčešća tranzitna inozemna odredišta bjegunaca bila su Italija, 69,2\%, i Austrija, 28,9\%, a ostale zemlje u mnogo manjem postotku. Cilj za 57\% prebjega zapravo su bile prekomorske zemlje, dok ih je samo $29 \%$ željelo ostati u Europi (HDA-CK SKH-OPS, 1957). Bjegunci koji bi uspjeli prijeći granicu i stići do željenih zemalja nisu međutim bili prepušteni sami sebi. U državama u koje su bježali, Italiji, Austriji i Njemačkoj, organizirani su već od kraja Drugoga svjetskog rata prihvatni logori, osim za ratne zarobljenike, i za civilne izbjeglice iz istočnoeuropskih zemalja. U Italiji su to bili logori Udine i Fraschette di Alatri, u Austriji logor Asten kod Linza, a u Njemačkoj logor Walka kod Nürnberga. Njima su upravljale policije država domaćina, a u njima su djelovale i razne humanitarne organizacije. Po dospijeću u logore bjegunce su ispitivali te su se morali očitovati o razlozima bijega. Većina ih se izjašnjavala da bježi iz političkih razloga, iako je za dio njih stvarni razlog bio ekonomski. No izbjeglice bi se deklarirale kao politički emigranti te bi tražile politički azil. Ako bi navele bilo koji drugi razlog zbog kojeg su emigrirale, bile bi vraćene u zemlju. Nakon boravka od nekoliko mjeseci, pa i duže, u prihvatnim logorima bjegunci su se ili naseljavali 
u tim državama ili su se prebacivali dalje, u prekooceanske zemlje, koje su većinom i bile njihovo ciljano odredište (HDA-CK SKH-OPS, 1957).

Valja spomenuti i osobe koje su legalno, s putnim ispravama, izlazile iz zemlje te zatim ostajale $u$ inozemstvu. Osim pojedinačnih slučajeva pedesetih su godina tako bježale i cijele grupe turista koje su autobusima preko agencija odlazile na izlete $u$ inozemstvo, odakle se više ne bi vratile (HDAIVS-OUP, 1956).

Bjegunci koji nisu uspjeli pobjeći i koji su pri pokušaju bijega preko granice bili uhvaćeni prolazili su policijsku »obradu«. Ispitivali su ih o razlozima i načinu bijega te o organizatorima i pomagačima u bijegu. Kazne su ovisile o njihovoj ulozi u bijegu, razlozima te eventualnom ponavljanju bijega. Za individualne pokušaje bijega kažnjavalo se samo prekršajno, no ako bi se pokušaji bijega ponovili, onda i kazneno preko Kotarskog suda. Kazne su bile od jednoga do nekoliko mjeseci zatvora. Osobe koje su bile u povratu ili one koje su uhvaćene u stometarskome graničnom pojasu također se optuživalo prekršajno.

Redovito se međutim kazneno progonilo organizatore grupa za bijeg, organizatore za prebacivanje preko granice koji to čine za novac ili iz drugih pobuda, zatim osobe koje su bježale od služenja u JNA te osobe koje su optužene za protupravno oduzimanje brodova pri bijegu. One su kažnjavane i sa po nekoliko godina zatvora (HDA-CK SKH-OPS, 1959).

I dok su prije Drugoga svjetskog rata svi ilegalni prijelazi granice tretirani samo kao prekršaji, u poratnoj Jugoslaviji postojala je gradacija - od prekršaja do kaznenog djela s predviđenim zatvorskim kaznama (HDA-CK SKH-OPS, 1957).

\section{BROJ BJEGOVA U INOZEMSTVO, REGIONALNA I RODNA PRIPADNOST TE DOB EMIGRANATA}

Koliko je ljudi u proučavanom razdoblju uspjelo ili pokušalo pobjeći iz Hrvatske? U literaturi se pojavljuje podatak da je od 1945. do 1963. ilegalno iz Jugoslavije pobjeglo ili otišlo legalnim putem, a zatim ostalo u inozemstvu oko 112.000 osoba, od kojih su 70\% činili mladi (Karakaš-Obradov, 2014: 112). To bi značilo da je u navedenom razdoblju prebjeglo oko 78.400 mladih, no ti podaci odnose se na cijelu Jugoslaviju, a ne samo na Hrvatsku. R. Radić (1999: 143-144) navodi podatke o 150.000 poslijeratnih ilegalnih emigranata i drugih osoba iz Jugoslavije do polovine šezdesetih, dok Z. Radelić (2006: 291) spominje da je u pedesetima u Austriji i Italiji iz Jugoslavije zabilježeno oko 2000 prebjega mjesečno. M. Bošković (1980: 61) navodi po- 
datak o 17.000 osoba koje su od 1945. do 1951. pobjegle u zapadne zemlje. Iako se navedeni podaci za ukupni broj ilegalnih emigranata razlikuju, što je najvjerojatnije posljedica nesustavne evidencije, činjenica je da su među iseljeništvom Jugoslavije najveći broj činili Hrvati - od otprilike 1.500.000 iseljenika početkom šezdesetih, 900.000 bilo je Hrvata - više nego iseljenika svih drugih republika zajedno (Radić, 1999: 144).

Za razdoblje 1949. - 1952. postoje podaci o bijegu u inozemstvo na razini Jugoslavije preuzeti iz dokumentacije Odbora za unutrašnju politiku SIV-a od 25. lipnja 1953. Iako se izvor čini vjerodostojan, broj prebjega doima se, ako ga usporedimo s onim za Hrvatsku sljedećih godina, premalenim (tablica 2).

Tablica 2. Broj ilegalnih prebjega iz Jugoslavije 1949. - 1952.

Table 2. Number of illegal runaways from Yugoslavia, 1949-1952

\begin{tabular}{lc}
\hline Godina & Broj prebjega \\
\hline 1949. & 1432 \\
\hline 1950. & 1590 \\
\hline 1951. & 2436 \\
\hline 1952. & 2455 \\
\hline
\end{tabular}

Izvor: Radić, 1999: 145.

Iako je u dokumentima Odbora za unutrašnju politiku SIV-a navedeno kako su to bjegovi zbog neprijateljske djelatnosti, u razradi razloga vidi se da su oni zapravo raznorodni. Na prvom je mjestu avanturizam, zatim rodbinske veze s inozemstvom, želja za lakšim i udobnijim životom i lakomislenost, što je još jedan dokaz da do 1955. nisu bježali samo politički protivnici sustava (Radić, 1999: 145).

Budući da za NRH ne postoje skupni podaci o broju ilegalnih prebjega mlade populacije za sve promatrane godine, pokušat ćemo predstaviti podatke kojima raspolažemo. Pritom treba uvažiti činjenicu kako predočeni podaci nisu cjeloviti zato što ih, pogotovo za prve poratne godine, u dostupnoj arhivskoj građi ili literaturi i nema. Do 1948. evidencije tog tipa nisu se vodile, pa ih ni u arhivskoj građi ne nalazimo te za to razdoblje raspolažemo samo sporadičnim podacima za pojedine tadašnje kotareve.

Najstariji dokumenti koji govore o ilegalnom bijegu mladih potječu iz 1949. i izradila ih je Komisija za ideološko-politički rad NOH-a. U pronađenim dokumentima govori se, temeljem poslanih izvješća kotarskih komiteta NOH-a, o nizu pokušaja bijega iz Jugoslavije u Italiju i Austriju, naročito 
iz pograničnih krajeva. Tada je primjerice iz Kukljice na Ugljanu pobjeglo dvanaest osoba, od kojih devet mladih, a jedan od organizatora bijega bio je član KP-a, sekretar aktiva NOH-a i član Plenuma Kotarskoga komiteta. Grupa se, kaže se u izvješću, pretvarala da ide u ribolov na područje Kornata te je tako pobjegla (HDA-RK SSOH-KIPR, 1951). I iz drugih je krajeva 1949. pobjegao određeni broj mladih - iz Krapnja pet, Korčule sedam, Rijeke dvadesetak, a iz Pule je pobjegao član biroa Gradskoga komiteta NOH-a. U Čakovcu su te godine održana tri suđenja, između ostaloga i za pokušaje bijega, dok su iz Kotoribe i Draškovca pobjegle četiri mlade osobe (HDARK SSOH-KIPR, 1949).

Za kotar Brač - Supetar pronađeni su ukupni podaci za razdoblje od 1945. do 1952., u kojem su pobjegle četiri osobe, a još ih je četiri pokušalo bijeg, ali su uhvaćene (HDA-RK SSOH-KIPR, 1952a).

Za razdoblje od 1948. do 1952. postoje ukupni podaci o bjegovima iz Hrvatske, ali samo za pojedine kotareve, a ne i za cijelu republiku. U dokumentu se navode podaci tek za dio priobalnih kotareva te onih u unutrašnjosti Istre, dok ih za kopneni dio Hrvatske nema. Također, u dokumentima se ne navodi odnose li se podaci o bijegu samo na mlade ili i na ostale dobne skupine stanovništva. Samim time ti podaci nisu potpuni ni precizni, ali mogu poslužiti kao ilustracija tadašnjega kretanja stanovništva u pogledu ilegalne emigracije.

Tablica 3. Ukupni podaci o bjegovima iz nekoliko kotareva Hrvatske 1948. - 1952.

Table 3. Total number of escapes from several districts of Croatia, 19481952

\begin{tabular}{lcccc}
\hline Kotar & Pobjegli & Uhvaćeni & Vratili se & Ukupno \\
\hline Korčula & 44 & & & 44 \\
\hline Brač & 5 & 3 & 9 & 8 \\
\hline Zadar & 85 & & & 94 \\
\hline Vis & 17 & 5 & 243 \\
\hline Labin & 103 & 140 & 239 \\
\hline Buzet & 121 & 118 & $417 / 477$ \\
\hline grad Rijeka & $40 / 100$ & 377 & 177 \\
\hline kotar Rijeka & 51 & 126 & $\mathbf{1 3 4 2 / 1 4 0 2}$ \\
\hline kotar Poreč & 40 & 58 & &
\end{tabular}

Izvor: HDA-RK SSOH-KIPR, 1952 b, c, d, e. 
Prema izvornim dokumentima NOH-a, od 1948. do 1952. su iz pojedinih kotareva Hrvatske pobjegle ili pokušale bijeg 1342 osobe ili, uzimajući u obzir i drugačije brojeve u tom dokumentu, 1402 osobe (tablica 3). Za Korčulu postoji podatak i da je od 1945. do 1956. pobjeglo 220, a spriječeno u bijegu 345 osoba (Karakaš-Obradov, 2014: 112).

Što kažu podaci o bjegovima od 1952.? Izvori nam govore da je samo 1952. iz Rijeke što pokušalo, što uspjelo pobjeći tridesetak mladih ljudi, a iz Čakovca i Poreča po četrdeset (HDA-RK SSOH-ORG, 1952a). S Lastova je te godine pobjeglo šest omladinaca, iz Blata na Korčuli osamnaest, a nekoliko ih je pokušalo bijeg, ali su uhvaćeni (HDA-RK SSOH-ORG, 1952b). Iz grada i kotara Zadra također je bio veliki broj prebjega - u 1952. pobjegle su 53 osobe, a od siječnja do studenoga 1954. čak 251 osoba. Većinu su činili mladi - u dobi od šesnaest do trideset godina bilo ih je 192 (Vojnović, 2008: 171).

Bježalo se i iz bivše oblasti Karlovac - u 1953. i 1954. pobjegle su 82 osobe, a iz bivših oblasti Zagreb, Bjelovar i Osijek 237 osoba (Vojnović, 2008: 180-182).

Tijekom 1953. iz Hrvatske je bijeg ukupno pokušalo 1406 osoba, od kojih je 499 uspjelo pobjeći, a ostale su uhićene i ispitivane (HDA-IVS-OUP, 1956; Vojnović, 2008: 178; Jakovina, 2003: 406). U 1954. taj je broj još narastao - na ukupno 2282 osobe koje su pokušale pobjeći (HDA-RK SSOH-KIPR, 1956; HDA-IVS-OUP, 1956). Prema podacima Izvršnoga komiteta CK SKH, taj je broj do 1. studenoga iznosio 2141, od čega je bijeg uspio za 957 osoba, dok ih je uhićeno 834, a 350 odvraćeno od bijega (Vojnović, 2008: 178).

Te je godine iz oblasti Dalmacija pokušala pobjeći 451 osoba, uspjele su u tome 262, dok ih je 111 uhićeno, a osamdeset odvraćeno od bijega. Iz oblasti Rijeka pokušalo je pobjeći 617 osoba, u tome su uspjele 273, uhićene su 322 , odvraćene od bijega 22, a 33 su nestale. Iz oblasti Karlovac pokušalo je bijeg 109 osoba, 82 su uspjele pobjeći, 25 je uhićeno, a četiri su odvraćene od bijega. Iz oblasti Zagreb, Bjelovar i Osijek pokušala je bijeg 621 osoba, 237 uspjelo ih je pobjeći, 294 su uhićene, a devedeset ih je odvraćeno od bijega. Od tog su broja samo iz grada Zagreba pokušale bijeg 353 osobe (Vojnović, 2008: 180-182).

Paralelno s navedenim podacima postoje i oni R. Radić (1999) preuzeti iz dokumenata SIV-a za godine 1953.-1956. U njima se navodi značajno manji broj ilegalnih emigranata s područja NRH i nije potpuno jasno kako je moglo doći do tolikog nerazmjera u brojevima. Ili se evidencija nije vodila dosljedno i jednoobrazno ili su se pravi brojevi prebjega u inozemstvo nastojali prikriti, vjerojatno iz političkih razloga. 
Tablica 4. Okvirni podaci o broju emigranata iz Hrvatske 1953. - 1961.

Table 4. Approximate data on the number of emigrants from Croatia, 1953-1961

\begin{tabular}{|c|c|c|c|c|c|}
\hline \multicolumn{5}{|c|}{ Podaci iz fondova HDA-e i literature } & \multirow{2}{*}{$\begin{array}{c}\begin{array}{c}\text { Podaci } \\
\text { SIV-a }\end{array} \\
\text { Pobjegli }\end{array}$} \\
\hline Godina & $\begin{array}{l}\text { Uhvaćeni i } \\
\text { odvraćeni } \\
\text { od bijega }\end{array}$ & Pobjegli & $\begin{array}{l}\text { Otputovali } \\
\text { legalno } \\
\text { i ostali u } \\
\text { inozemstvu }\end{array}$ & Ukupno & \\
\hline 1953. & 907 & 499 & \multirow{3}{*}{$\begin{array}{c}\text { nema } \\
\text { podataka }\end{array}$} & 1406 & 500 \\
\hline 1954. & 1184 & 957 & & $\begin{array}{l}2141 / \\
2282\end{array}$ & 1039 \\
\hline 1955. & $\begin{array}{c}\text { nema } \\
\text { podataka }\end{array}$ & $\begin{array}{c}\text { nema } \\
\text { podataka }\end{array}$ & & 2861 & 1234 \\
\hline $\begin{array}{l}1956 . \\
\text { (do 31. 8.) }\end{array}$ & 3429 & 4022 & 424 & 7875 & 4198 \\
\hline 1957. & 8200 & 8157 & \multirow{3}{*}{$\begin{array}{c}\text { nema } \\
\text { podataka }\end{array}$} & 16.357 & \multirow{5}{*}{$\begin{array}{c}\text { nema } \\
\text { podataka }\end{array}$} \\
\hline 1958. & 6516 & 4020 & & 10.536 & \\
\hline 1959. & 4172 & 3511 & & 7683 & \\
\hline 1960. & 3992 & 3109 & $\begin{array}{c}123 \\
\text { (do 31. 5.) } \\
\end{array}$ & 7224 & \\
\hline $\begin{array}{l}1961 . \\
\text { (do 31. 10.) }\end{array}$ & 3586 & 3025 & $\begin{array}{c}246 \\
\text { (do 31. 5.) } \\
\end{array}$ & 6857 & \\
\hline \multirow[t]{2}{*}{$\begin{array}{l}\text { Okvirni broj } \\
\text { ilegalnih } \\
\text { emigranata iz } \\
\text { Hrvatske } \\
\text { 1953. - 1961. }\end{array}$} & 31.986 & 27.300 & 793 & $\begin{array}{c}62.940 / \\
63.081\end{array}$ & $\begin{array}{c}\text { Ukupno } \\
\text { prema } \\
\text { SIV-u }\end{array}$ \\
\hline & & & & & 6971 \\
\hline
\end{tabular}

Izvori: HDA-RK SSOH-KIPR, 1956; HDA-IVS-OUP, 1956; Radić, 1999: 146; Vojnović, 2008: 178; Jakovina, 2003: 406.

Godine 1955. iz cijele je Jugoslavije, za usporedbu, prema podacima R. Radić (1999), pobjeglo 3850 osoba, od kojih je 2968 ilegalno prešlo granicu, 818 ostalo je u inozemstvu s urednim pasošima, a preostalih 66 bili su mornari koji su dezertirali s brodova. Iz Hrvatske su, prema istim podacima, u 1955. pobjegle 1234 osobe, što odudara od podataka u izvorima HDA-e, koji za istu godinu navode više nego dvostruko bjegova - 2861 (Radić, 1999: 146). 
Za godine nakon 1953. u izvorima HDA-e nemamo pojedinačnih podataka o bijegu prema kotarevima, već samo ukupni broj prebjega po pojedinim godinama. No za 1956. raspolažemo podacima samo za prvih osam mjeseci, a za 1961. za prvih deset mjeseci u godini, pa ni ti podaci nisu potpuni. Ono što se jasno primjećuje jest da tih godina, od 1953. do 1957., broj bjegunaca sve više raste i kulminira u 1957., kada je iz NRH pokušalo pobjeći rekordnih 16.357 osoba, od kojih je to i uspjelo 8157 osoba (HDA-RK SSOH-KIPR, 1956). Za tu godinu u literaturi postoji podatak da je ukupno iz Jugoslavije pobjeglo ili pokušalo bijeg više od 25.000 osoba (Bošković, 1980: 63). Tih je godina primjerice naglo porastao broj molbi za dobivanje američke vize upućenih američkoj ambasadi - s dvjestotinjak 1954. na 4611 mjesečno 1956.

Od tada ukupni broj prebjega lagano pada, ali je karakteristično povećanje broja bjegova iz unutrašnjosti (Karlovac, Zagreb, Osijek itd.) (HDA-RK SSOH-KIPR, 1956). Pad broja bjegunaca od 1957. vlasti su objasnile provedbom velike akcije društveno-političkih organizacija (SSRNH, NOH) na sprečavanju bjegova, što je uključivalo poboljšanje životnih uvjeta na ugroženim područjima, gospodarski rast i otvaranje radnih mjesta. U 1961. ponovno se međutim pojavljuje tendencija rasta.

Ako zbrojimo pokušaje i uspjele bjegove od 1953. do 1961. prema izvorima HDA-e, dobit ćemo broj od ukupno 63.081 osobe. Od toga je uspjelo pobjeći 27.300 osoba, dok ih je 31.986 uhvaćeno pri pokušaju bijega, a 793 legalno su otputovale, a zatim ostale u inozemstvu. Za njih nemamo potpune podatke - samo za prvih sedam mjeseci 1956. te za prvih pet mjeseci 1960. i 1961. I taj nedostatak u evidenciji upućuje nas na zaključak da je i emigranata iz te skupine zacijelo bilo više.

Iz kojih se hrvatskih krajeva najviše bježalo? Logično je da su to, kako je već napomenuto, bili pogranični krajevi, a, ukupno gledajući, najviše je ljudi u inozemstvo pobjeglo iz kotareva Rijeke, Pule, Zagreba, Zadra, Šibenika i Splita. Iz tih je kotareva poteklo $74 \%$ svih ilegalnih emigranata. Nešto se manje bježalo iz Dubrovnika i zagorskih kotareva, a najmanje iz kotareva Bjelovar, Daruvar, Križevci, Virovitica, Krapina i Slavonska Požega. Iz Dalmacije je najviše osoba pobjeglo iz kotareva Zadar (pogotovo s Pašmana), Šibenik, Split, Korčula i Hvar, a iz bivše oblasti Rijeka iz grada Rijeke, zatim grada i kotara Pula te kotareva Labin, Poreč, Lošinj i Delnice (HDA-RK SSOH-KIPR, 1956).

Prema analizi NOH-a, prosječno je na svaka 583 stanovnika NRH jedan pokušao bijeg. Taj je omjer bio veći u Puli (218), Karlovcu (286), Rijeci (295), Zadru (378), Ogulinu (408), Čakovcu (461), Zagrebu (490), Slavonskom Brodu i Makarskoj (570), dok je u ostalim kotarevima bio manji. Valja napome- 
nuti kako je područje Pule bilo specifično jer je tamo stanovništvu bio dozvoljen i takozvani »malogranični promet« - legalni odlasci u Italiju (Trst) do četiri puta mjesečno iz poslovnih razloga, čime se mnogo ljudi koristilo, a dio ih je nakon legalnog prelaska granice i ostajao u Italiji (HDA-RSPPPO, 1958).

Prema rodnoj pripadnosti, većina bjegunaca bili su muškarci (86\%), dok je žena bilo tek $14 \%$. Od svih bjegunaca $64,2 \%$ bilo je u dobnoj skupini od 18 do 25 godina, a 35,7\% bilo ih je u dobi iznad 25 godina. Također, $71 \%$ svih bjegunaca bilo je neoženjeno/neudano (HDA-RK SSOH-KIPR, 1956).

\section{STAV VLASTI PREMA BJEGOVIMA}

Jugoslavenske su vlasti od 1945. do sredine pedesetih nastojale spriječiti iseljavanje iz Hrvatske te nisu blagonaklono gledale na bijeg iz zemlje. Jedan je razlog bio taj što se nije željelo poticati stvaranje »nove ekonomske emigracije« (Karakaš-Obradov, 2014: 112), a drugi je bio moguće stvaranje negativne slike o jugoslavenskome socijalističkom sustavu koju bi ilegalni emigranti mogli prezentirati u državama naseljavanja. Takvo što vlasti nisu željele jer im bilo bitno kako je Jugoslavija predstavljena u svijetu. Sredinom šezdesetih u emigraciji je već djelovalo više od 190 raznih organizacija, a vlasti u Jugoslaviji od tog su njih 135 smatrale neprijateljskima. Tada je izlazilo i 136 emigrantskih listova, u nakladi većoj od 900.000 primjeraka (Radić, 1999: 146).

Zbog sve učestalijega ilegalnog iseljavanja unutar KP/SK i NOH-a te Izvršnog vijeća NRH i Saveznoga izvršnog vijeća tražilo se rješenje problema. Osim već navedenih razloga dio problema pronađen je i u nezadovoljavajućoj aktivnosti vlasti i tadašnjih društveno-političkih organizacija (DPOa) prema fenomenu bijega mladih. U izvornim dokumentima spominje se tako ravnodušnost omladinskih rukovodilaca prema bjegovima, koji prema toj pojavi često nisu imali nikakvih komentara »osim uobičajenih naklapanja o avanturizmu i rodbini u Americi«. Navodi se i kako se nerijetko znalo tko će i kada bježati, a ništa se nije poduzimalo. U razloge za bijeg mladih voditelji NOH-a ubrajali su i nedovoljno kritičan odnos prema Zapadu i njegovu društvenom sustavu, zatim »jak rad neprijatelja«, a u Rijeci i teške uvjete života učenika škola u privredi, koji su učestalo bježali (HDA-RK SSOH-KIPR, 1949). U zapisnicima sjednica Odbora za unutarnju politiku IV NRH iz 1958. navodi se i kako se u Rijeci spremao pobjeći iz zemlje cijeli jedan završni razred zbog percepcije neperspektivnosti za mlade u tadašnjoj Hrvatskoj i Jugoslaviji (HDA-RSPP-PO, 1958). 
U partijskoj i omladinskoj organizaciji u vezi s bijegom mladih gledišta nisu bila usuglašena. Djelomice je vladalo mišljenje da se prebjege treba tretirati kao neprijatelje jer su napustili zemlju, drugi su smatrali da za njima ne treba žaliti jer su ionako "probisvijeti i ljenčine«, pa ih se bolje riješiti, dok su treći nastojali objektivno sagledavati okolnosti zbog kojih su mladi bježali tražeći izlaz iz toga. Prilično je rašireno bilo i shvaćanje da je sankcioniranje bjegova stvar Udbe, pa se SK i omladinske organizacije $u$ to nisu htjeli ni miješati (HDA-RK SSOH-KIPR, 1956). Neki su smatrali i da je svaki bijeg političkoga karaktera te da ga tako treba i tretirati.

Čelnici SK i tadašnjih društveno-političkih organizacija, SSRNH i NOHa, međusobno su prebacivali odgovornost za takvo stanje. U SK vladalo je mišljenje kako se $\mathrm{NOH}$ nije dovoljno bavio tim pitanjem i sprečavanjem odlaska mladih van te osiguravanjem atmosfere i uvjeta za njihov ostanak, a u NOH-u su smatrali kako se SK nije dovoljno angažirao u pomoći oko sprečavanja bijega mladih.

Kako bi se mlade uvjerilo da ostanu u Jugoslaviji, predlagalo se osiguravanje boljih ekonomskih uvjeta - razvoj otoka, elektrifikacija, razvoj turizma i općenito gospodarstava te pojačanje promidžbe $\mathrm{i}$ »ideološkog rada« $\mathrm{S}$ mladima (HDA-RK SSOH-KIPR, 1956).

Na sjednici SIV-a 18. travnja 1956. zaključeno je da treba nešto poduzeti kako bi što manje građana ostajalo u inozemstvu i bježalo iz zemlje. Postavljalo se i pitanje rješavanja tradicije emigracije u hrvatskom priobalju, zbog čega je od kraja Drugoga svjetskog rata pa do sredine pedesetih iz Dalmacije, Like i Primorja bilo zabranjeno iseljavanje. Ipak, ilegalno iseljavanje upravo je iz tih krajeva bilo učestalo, pa su vlasti već tada ozbiljno razmatrale ideju o ublažavanju kriterija za ekonomsko iseljavanje i liberalizaciji izdavanja putovnica, pogotovo kada je riječ o članovima obitelji. Odbor za unutrašnju politiku NRH zastupao je mišljenje kako svima koji zbog ekonomskih problema traže izlaz u emigriranju treba omogućiti da se isele jer su smatrali da je bolje da kontroliraju legalno iseljavanje nego da ljudi bježe u inozemstvo. Tada je predloženo i da SIV razmotri mogućnost o sklapanju ugovora sa zapadnim zemljama o zapošljavanju radnika iz Jugoslavije, što će se uskoro ostvariti odlukom SIV-a o potpisivanju Sporazuma o zapošljavanju radnika s pojedinim državama, čime će početi sljedeći val ekonomske emigracije (HDA-RK SSOH-KIPR, 1956; Karakaš-Obradov, 2014: 113; Radić, 1999: 148, 151). 


\section{ZAKLJUČAK}

Ilegalna emigracija u Hrvatskoj bila je prisutna od završetka Drugoga svjetskog rata i trajala je u sve većem opsegu do početka šezdesetih godina 20. stoljeća, kada država postupno otvara granice i liberalizira se izdavanje putnih isprava. Ilegalno su emigrirali većinom mladi ljudi, do 25 godina, i to prije svega iz ekonomskih razloga, što je povezano s tradicijom emigracije, pogotovo u priobalnom području. Pritom su veliku ulogu odigrale rodbinske i regionalne veze s već postojećom i materijalno osiguranom prijeratnom ekonomskom emigracijom.

Osim zbog loše ekonomske situacije emigriralo se i iz političkih razloga - neslaganja s državnim i društvenim sustavom, zatim iz avanturizma, zbog izbjegavanja služenja u JNA ili bijega od kaznene odgovornosti za počinjena djela. Bježalo se kopnenim putem - pješice ili vlakom, te morskim putem - raznovrsnim brodicama, što je bilo i mnogo uspješnije. Najčešće odredišne zemlje, koje su većinom bile tranzitnoga karaktera, bile su Italija, Austrija i Njemačka, odakle se većina emigranata prebacivala u prekomorske zemlje. Vrhunac ilegalne emigracije bila je 1957., kada je iz NRH na taj način pokušalo pobjeći 16.357, dok je u tome uspjelo i iselilo se 8157 osoba.

Egzaktnih podataka o broju emigranata ove vrste nema jer su izvori i literatura vrlo oskudni, a u postojećima se podaci razlikuju. Iz Hrvatske je najviše ljudi bježalo iz tadašnjih kotareva Rijeka, Pula, Zagreb, Zadar, Šibenik i Split, iz kojih je potjecalo 74\% svih ilegalnih emigranata. Prebjezi su većinom bili radnici, 59,7\%, i to mlađi ili nekvalificirani, koji su imali vrlo niska primanja, a slijedili su zemljoradnici, učenici škola u privredi, službenici, učenici i studenti, pomorci, obrtnici i dr. Prema rodnoj pripadnosti, među prebjezima je bilo mnogo više muškaraca, $84 \%$, nego žena, $16 \%$, od kojih je 71\% bio neoženjeno/neudato.

Vlasti i društveno-političke organizacije radile su na sprečavanju bijega u inozemstvo metodama nadzora granice i zatvorskim kaznama za organizatore i ponavljače u bijegu, ali i pokušajima osiguravanja boljih ekonomskih uvjeta i života u područjima u kojima je emigriranje poprimilo veće razmjere. Budući da te mjere nisu dale željene rezultate, ali i zbog početaka gospodarske krize te pojave nezaposlenosti, vlasti su liberalizirale postupke iseljavanja i otvorile granice potencijalnim iseljenicima, što je dovelo do novog vala ekonomske emigracije od šezdesetih godina 20. stoljeća. 


\section{LITERATURA}

Bilandžić, D. (1999). Hrvatska moderna povijest. Zagreb: Golden marketing.

Bošković, M. (1980). Antijugoslovenska fašistička emigracija. Beograd - Novi Sad: Sloboda - Dnevnik.

Dukovski, D. (2001a). Egzodus talijanskog stanovništva iz Istre 1945. - 1956., Časopis za suvremenu povijest, 33 (3): 633-667.

Dukovski, D. (2001b). Rat i mir istarski: model povijesne prijelomnice (1943. - 1955.). Pula: C.A.S.H.

Geiger, V. (2002). Folksdojčeri: pod teretom kolektione krionje. Osijek: Njemačka narodnosna zajednica.

Goldstein, I. (2008). Hrvatska 1918. - 2008. Zagreb: Europapress holding - Novi Liber.

Jakovina, T. (2003). Američki komunistički saveznik: Hrvati, Titova Jugoslavija i Sjedinjene Američke Države 1945. -1955. Zagreb: Profil - Srednja Europa.

Karakaš-Obradov, M. (2013). Emigracije talijanskog stanovništva s hrvatskog područja tijekom Drugog svjetskog rata i poraća, Radovi za povijesne znanosti HAZU u Zadru, 55: 204-225.

Karakaš-Obradov, M. (2014). Novi mozaici nacija u »novim poredcima«: migracije stanovništva na hrvatskom području tijekom Drugoga svjetskog rata i poraća. Zagreb: Hrvatski institut za povijest.

Lajić, I. (1992). Stanovništvo dalmatinskih otoka - povijesne i suvremene značajke depopulacije. Zagreb: Consilium - Institut za migracije i narodnosti Sveučilišta u Zagrebu.

Lalić, V. (2010). Egzodus iz Australije u doba Hladnog rata: povratak hrvatskih iseljenika brodovima Partizanka i Radnik godine 1948-1949., Gordogan, 8 (19-22): 66-126.

Maticka, M. (1990). Agrarna reforma i kolonizacija u Hrvatskoj od 1945. do 1948. Zagreb: Školska knjiga - Stvarnost.

Mesarić Žabčić, R. (2014). Fenomen prekooceanske lančane migracije i lokalni/regionalni identiteti, u: C. Hornstein Tomić i dr. (ur.). Hrvatsko iseljeništvo i domovina: razvojne perspektive. Zagreb: Institut društvenih znanosti Ivo Pilar, 77-87.

Nejašmić, I. (1991). Iseljavanje iz Hrvatske - brojčani aspekti stoljetnog procesa, u: I. Crkvenčić (ur.). Političko-geografska i demografska pitanja Hrvatske. Zagreb: Savez geografskih društava Hrvatske, 61-81.

Nejašmić, I. (2014). Iseljavanje iz Hrvatske od 1900. do 2001.: demografske posljedice stoljetnog procesa, Migracijske i etničke teme, 30 (3): 405-435, doi: 10.11567/met.30.3.6.

Radelić, Z. (2006). Hrvatska u Jugoslaviji 1945. - 1991.: od zajedništva do razlaza. Zagreb: Školska knjiga.

Radić, R. (1999). Iseljavanje stanovništva sa jugoslovenskog prostora polovinom pedesetih godina, Istorijski zapisi, (1-2): 143-173.

Selinić, S. (2010). Jugoslovensko-čehoslovački odnosi 1945 - 1955. Beograd: Institut za noviju istoriju Srbije.

Spehnjak, K. (2006). Britanski pogled na Hrvatsku 1945. - 1948. Zagreb: Golden marketing - Tehnička knjiga.

Šarić, T. (2011). Položaj i uloga omladine i omladinskih organizacija u FH / NRH 1945. - 1954. (doktorska disertacija). Zagreb: Filozofski fakultet Sveučilišta u Zagrebu. 
Vojnović, B. (prir.) (2006). Zapisnici Politbiroa Centralnog komiteta Komunističke partije Hrvatske 1945. - 1952. Sv. II. Zagreb: Hrvatski državni arhiv.

Vojnović, B. (prir.) (2008). Zapisnici Izvršnog komiteta Saveza komunista Hrvatske 1952. -1954. Sv. III. Zagreb: Hrvatski državni arhiv.

Žerjavić, V. (1993). Doseljavanja i iseljavanja s područja Istre, Rijeke i Zadra u razdoblju 1910 - 1971., Društvena istraživanja, 2 (4-5[6-7]): 631-656.

\section{IZVORI}

Hrvatska, Hrvatski državni arhiv (HR-HDA)-1220. Centralni komitet Saveza komunista Hrvatske (CK SKH):

Organizaciono-politički sekretarijat (OPS), 7. Odnosi s tijelima vlasti: »Problem bijega u inostranstvo«, 5. 3. 1957. (HDA-CK SKH-OPS, 1957)

Zapisnik sa VI. sjednice Savjeta za unutrašnje poslove NO kotara Zadar, 17. 9. 1959. (HDA-CK SKH-OPS, 1959)

Elaborat o problemima i pojavama u vezi s putovanjima naših građana u inozemstvo, b.g. (HDA-CK SKH-OPS, b.g)

HR-HDA-1231. Republička konferencija Saveza socijalističke omladine Hrvatske (RK $\mathrm{SSOH})$ :

Organizacijsko odjeljenje (ORG):

Stenografski zapisnik sa sastanka ekipe CK KPH, 4. 4. 1952., br. 767. (a) (HDA-RK SSOH-ORG, 1952a)

Izvještaj o radu NOH i CK u 1952. godini. (b) (HDA-RK SSOH-ORG, 1952b)

Komisija za ideološko-politički rad (KIPR):

Bijeg preko granice, dokumenti:

»Neke napomene u vezi s pojavama bjekstva omladine $\mathrm{u}$ inostranstvo«, 1949. (HDA-RK SSOH-KIPR, 1949)

Izvještaj KK NOH-a Zadar-otoci upućen CK NOH-u, 4. 9. 1951.

Izvještaj KK NOH-a Supetar-Brač upućen CK NOH-u, 10. 12. 1952. (a) (HDARK SSOH-KIPR, 1952a)

Podaci o prebjeglim omladincima u inostranstvu i informbirašima od 1948. do konca 1952., 20. 12. 1952. (b) (HDA-RK SSOH-KIPR, 1952b)

Izvještaj KK NOH-a Korčula upućen CK NOH-u, 11. 12. 1952. (c) (HDA-RK SSOH-KIPR, 1952c)

Izvještaj KK NOH-a Zadar upućen Oblasnom komitetu NOH-a Split, 12. 12. 1952. (d) (HDA-RK SSOH-KIPR, 1952d)

Izvještaj GK NOH-a Rijeka upućen CK NOH-u, 16. 12. 1952. (e) (HDA-RK SSOH-KIPR, 1952e)

Dokument Problem bijega u inozemstvo, 30. 9. 1956. (HDA-RK SSOH-KIPR, 1956)

Dokument »Neki društveno-politički aspekti bijega«, 1961. (a) (HDA-RK SSOH-KIPR, 1961a)

Izvještaj GK NOH-a Zagreb »Pregled bjegova od 1. 1. -10. 8. 1961.« (b) (HDARK SSOH-KIPR, 1961b) 
HR-HDA-280. Izvršno vijeće sabora Socijalističke Republike Hrvatske (IVS SRH), Sjednica Odbora za unutrašnju politiku (OUP) IV NRH, 24. 12. 1956. (HDA-IVSOUP, 1956)

HR-HDA-1984. Republički sekretarijat za pravosudne poslove (RSPP), Pravni odjel (PO), Sjednica Odbora za unutrašnju politiku (OUP) IV NRH, 5. 6. 1958. (HDARSPP-PO, 1958) 


\section{Escape from Socialist Yugoslavia - Illegal Emigration from Croatia from 1945 to the Beginning of the 1960s}

\section{Tatjana Šarić}

\section{SUMMARY}

In the post-war socialist Yugoslavia political and/or economic situation has become unacceptable for part of the population. Since legal emigration from Croatia was not allowed, the number of illegal immigrants increased since the end of World War II. The article deals with this group of migrants using the comparative analysis of original archival materials and available literature in the period from 1945 to 1961 when the state began to gradually open the border. Mostly young people, under 25 years of age, immigrated illegally, mainly for economic reasons, and this was associated with a tradition of emigration, especially in the coastal region. In addition to the poor economic situation, people also emigrated for political reasons, then for adventure, to avoid serving in the Yugoslav People's Army or to escape from the law for committing criminal offenses. They were fleeing by land or by sea, which was much more successful. Usually the first destinations of the immigrants were Italy, Austria and Germany, from where the majority of them moved to overseas countries. Most people fled the districts of Rijeka, Pula, Zagreb, Zadar, Šibenik and Split that existed at that time so that $74 \%$ of all illegal immigrants came from them. The runaways were mostly workers, followed by farmers, vocational school students, public servants, pupils and students, sailors and craftsmen. According to gender, there were many more men than women among the runaways, most of whom were unmarried. The authorities were trying to prevent the escape abroad by methods of controlling the border and prison sentences, but also by the attempts to ensure better living conditions in the affected areas. As these measures had not yielded the desired results, but also due to the beginning of the economic crisis and the appearance of unemployment, the authorities liberalized emigration procedures and opened the borders to immigrants which resulted in a new wave of economic emigration.

KEY WORDS: socialism, FRY, Croatia, emigration, illegal emigration, youth 